Article

\title{
The Sustainability of Urban Food Systems: The Case of Mozzarella Production in the City of Milan
}

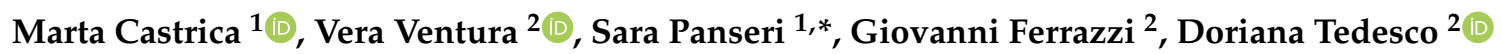 \\ and Claudia Maria Balzaretti ${ }^{1}$ (D) \\ 1 Department of Health, Animal Science and Food Safety, Università degli Studi di Milano, 20122 Milano, \\ Italy; marta.castrica@unimi.it (M.C.); claudia.balzaretti@unimi.it (C.M.B.) \\ 2 Department of Environmental Science and Policy, Università degli Studi di Milano, 20122 Milano, Italy; \\ vera.ventura@unimi.it (V.V.); giovanni.ferrazzi@unimi.it (G.F.); doriana.tedesco@unimi.it (D.T.) \\ * Correspondence: sara.panseri@unimi.it; Tel.: +39-0250317931
}

Received: 13 December 2019; Accepted: 14 January 2020; Published: 17 January 2020

\begin{abstract}
Background: Urban food production in the developed world has recently been facing the challenge of feeding the world's cities adequately and on a sustainable basis, and innovative models of food production can help this transition. Nevertheless, this field of research largely focuses on primary food production-so-called urban farming-while the subsequent steps of the food chain have scarcely been investigated. In this context, this study aimed to provide a preliminary evaluation of urban food processing, taking mozzarella cheese production in the city of Milan as a case study. Methods: Five urban farmers participated in a direct survey aiming at identifying how sustainable this specific production chain can be considered. Results: Results demonstrated that the concept of urban food production is really valorized through measures able to enhance the global sustainability of the food production process only in some of the dairy micro- enterprises and that the economic dimension must be considered the variable most critically involved in hampering the global sustainability of this specific food chain. Conclusions: This research suggests the need to disseminate a global governance of urban supply chains and to support local activities, which represent a sensitive and strategic sector.
\end{abstract}

Keywords: urban food production; short chain; sustainable production; micro dairies; mozzarella

\section{Introduction}

The ability of urban food systems to implement innovative ways of organizing the food chain, to achieve shared goals of sustainability and social inclusion, is an emerging issue in recent years $[1,2]$. Urbanization is a rapidly growing global trend, since an estimated sixty-eight percent of the world's total population will live in cities by 2050 [3]. The consequences of urbanization will necessarily include the challenge of feeding the world's cities adequately and on a sustainable basis and will thus require changes in the socioeconomic and environmental asset of urban food production and consumption, including measures for food and nutrition security [4,5]. Starting from the assumption that food is normally produced outside city limits, a recent study commissioned by the European Commission [6] attested to the emerging role of cities in introducing innovative strategies along the food supply chain for sustainable and healthy production, delivery, and consumption of food in cities. Through the analysis of some case studies, the same report mapped innovative solutions for sustainable and healthy production, delivery, or consumption of food in cities, concluding that the ambition is to develop holistic strategies that encompass and integrate all the areas of work related to food, social economy, environment, and health. Thus, the interest of the scientific community is moving toward the goal of studying this innovative form of production and marketing of food products in cities [7-10]. 
Literature suggests that the peculiarity of the new urban food systems relies on the fact that such systems include and convey several well-known drivers of modern rural development (i.e., short supply chain and local food) and different dimensions of the global concept of sustainability. As an example, producers and public institutions have been increasingly aware about the concept of a short supply chain for some years, and consumers are more and more interested in purchasing food products characterized by such attributes [11-15]. In 2013, the European Commission defined the short food supply chain (SFSC) as "a supply chain involving a limited number of economic operators, committed to cooperation, local economic development, and close geographical and social relations between producers, processors and consumer" [16]. Beyond the so called 'traditional' SFSCs, usually farm-based and located in rural areas, the neo traditional SFSCs consist of more complex collaborative networks, often located in urban or peri-urban areas, primarily supported by urban residents.

Moreover, the concept of Urban Food Systems is strongly connected to the idea of local, or the so-called "zero miles" food production. A local food system is defined as a collaborative effort in a particular place to build more locally based, self-reliant food systems and economies, in which sustainable food production, processing, distribution, and consumption is integrated to enhance the economic, environmental, and social health of a particular place [8]. The consumption and purchase of local products create added value for the rural location and encourage biodiversity in production. Several authors $[17,18]$ suggest that this type of economy is beneficial to the local economy, farmers, consumers, and the environment. In particular, a local economy can lower prices for consumers and be more profitable for producers, allowing farmers greater control over their economic lives [18], and delivering healthy products at competitive prices to consumers [17], together with the reduction in energy consumption and pollution associated with food transportation and storage conditions.

Finally, urban food production relates to the "city making" concept, wherein the entire production cycle takes place within cities and is meant to meet local demand for food products [19]. Urban producers are "community builders" or people who belong to the local community, interpret cultures and multiple identities, and promote urban skills and job opportunities, and include the recent trend of micro production [20].

Nevertheless, in spite of the large body of abovementioned literature, the idea of urban food production often refers only to urban agriculture, referred to as the growing of plants for food within and around cities or towns [21,22]. The focus on the benefits of urban agriculture has led to an association of urban agriculture with food justice for the enhanced access to fresh and healthy food and the increase in knowledge of nutrition and fresh food [23]. By contrast, the practice of urban agriculture also presents several constraints, such as the lack of infrastructure and support for urban farmers, the role of urban farming in city self-sufficiency and the impact of air pollution on urban agriculture [24].

If urban agriculture is a topic that has received great attention from the scientific community, conversely, secondary food processing in urban areas is a field of research with a very limited quantity of study.

A second point that needs to be further investigated is the fact that some studies suggest that such a transition towards more sustainable urban food systems has made food neither cheap nor easy [25] and that, in some cases, urban food production has been found to be not particularly sustainable, thus warning against the tendency to conflate terms such as 'local', 'alternative', 'specialty', and 'sustainable' [26-28]. Given the aforementioned scenario, the aim of this study was to widen the scope of scientific analysis beyond primary food production, as a means of improving the understanding on the development of innovative urban food systems. More specifically, the study aimed to provide a preliminary evaluation of urban food processing, taking as a case study mozzarella cheese production in the city of Milan, and by identifying how sustainable this specific production chain can be considered. Moreover, this research suggests the need to include the qualitative characteristics of the final product, regarding food safety and consumer preferences, in the evaluation, in order to obtain a more holistic evaluation of urban food systems. 
The reason behind the focus on Mozzarella cheese is that, in Italy, this product is endowed with very high attributes related to tradition, artisanal expertise and food culture. Italy is one of the major cow-milk mozzarella producers and consumers; in 2015, a total of 253,000 tons of mozzarella were produced in Italy, and consumption per capita was $4.6 \mathrm{~kg}$ [29]. Finally, the study is focused on the Milan urban area principally due to the fact that this city is at the forefront in the development of urban food policy. The Milan Urban Food Policy Pact (http://www.milanurbanfoodpolicypact.org/) was signed in 2014, together with 193 other cities, and aims to develop sustainable food systems, promote healthy diets, and fight unsustainable production and consumption patterns.

\section{Materials and Methods}

A total of seven micro dairies were identified in the city of Milan, but only five urban farmers had the production of mozzarella cheese as their core activity and agreed to participate in the study. During the first part of the analysis, data were collected through a direct survey, using an ad hoc questionnaire intended to gather information on sustainable production variables. The second part of the study focused on a more empirical evaluation of the product and considered issues regarding food safety, consumer preference, and the analysis of the aromatic profile of mozzarella cheese produced by the urban micro dairies.

\subsection{Characterization of the Micro Dairies Investigated}

The five micro dairies that participated in the study were characterized mainly by evaluating the following: (i) the distance between farm and micro dairy (milk delivery), (ii) the quantities of milk managed (ton/day), (iii) the quantities of mozzarella produced (kg/day), and then (iv) the management of by-products and wastewater disposal. The characterization shows that, in four cases, the distance between the farms and the micro dairies is between 30 and $50 \mathrm{~km}$, except for one where the kilometers are over $250 \mathrm{~km}$, specifically $920 \mathrm{~km}$. In regard to the quantities of milk managed, all the micro dairies are in a range between 6 and 10 tons/day, while the quantities of mozzarella produced are within a range of 20-40 kg/day. Instead, as for waste management in the micro dairies, the investigation showed that the main by-product of milk processing is whey, which, in accordance with the EU regulations in force (2017/1017/EC), can be reused for animal feed. In fact, as also described by other authors [30], the use of different by-products from the agrifood chain, including dairy by-products for feeding farm animals, is already a traditional practice in animal husbandry. Even though it has always been implemented by the processing industry, the "good practice" of reuse of resources still suitable for animal feed currently has a significant impact on the issue of "sustainability of supply chains".

The last topic evaluated to characterize the sustainability of the micro dairies analyzed was wastewater disposal. In our case study, they are micro dairies in the Lombardy territory-the Lombardy Region has published Regional Regulation No. 6 of 29 March 2019, in the Official Bulletin regarding the discharge of urban and domestic wastewater in which, for small agrifood companies belonging to the dairy sector with a production of wastewater not exceeding $20 \mathrm{mc} / \mathrm{g}$, disposal is assimilated to domestic wastewater, hence resulting in a lower environmental impact compared to the intensive dairy industry, also taking into account that lower production volumes require less use of water resources.

\subsection{Sustainability Related Variables}

The questionnaire was structured with questions regarding the three main pillars of sustainable production, composed of environmental, social, and economic aspects. Table 1 presents the list of the variables used and the scores assigned for the construction of the indices. The environmental dimension of sustainability was evaluated by considering the following variables: distance from milk production, raw material, organic and typical. The first variable accounts for the length (in kilometers) of the route that milk needs to cover to reach the urban production site. Consequently, this variable relates to the concept of "zero miles" production and the related benefits in terms of greenhouse gas 
emission reduction. The variable raw material describes the nature of the primary product used by micro dairies to make mozzarella cheese and can be considered a good proxy for the estimation of the level of wholesomeness of mozzarella cheese. Indeed, the artisanal and traditional mozzarella-making process is normally performed by using raw milk as a primary product, further transformed into mozzarella cheese by the cheesemaker. Nevertheless, in some of the micro dairies sampled, the raw material was not the milk itself, and consequently this variable has been included to take into account this specific aspect.

Table 1. Variables description.

\begin{tabular}{|c|c|c|c|c|}
\hline & & Interval & & Score \\
\hline \multirow[t]{10}{*}{ Environmental dimension } & Distance from production site & $0-50$ & $\mathrm{~km}$ & 3 \\
\hline & & 50-100 & $\mathrm{km}$ & 2 \\
\hline & & $100-250$ & $\mathrm{~km}$ & 1 \\
\hline & & $>250$ & $\mathrm{~km}$ & 0 \\
\hline & Raw material & Milk & & 1 \\
\hline & & Curd & & 0 \\
\hline & Organic farming & Organic & & 1 \\
\hline & & Traditional & & 0 \\
\hline & Typical races & Yes & & 1 \\
\hline & & No & & 0 \\
\hline \multirow[t]{6}{*}{ Social dimension } & Food Experience & $\begin{array}{l}\text { Mozzarella-making visible } \\
\text { for customer }\end{array}$ & & 1 \\
\hline & & not visible & & 0 \\
\hline & Presence of restaurant & Yes & & 1 \\
\hline & & No & & 0 \\
\hline & Social media & Use of social media & & 1 \\
\hline & & No social media & & 0 \\
\hline \multirow{6}{*}{ Economic dimension } & Price & Mozzarella Price & Euro/kg & \\
\hline & Delta price & & $\%$ & \\
\hline & Delta Price index & $0-100$ & $\%$ & 3 \\
\hline & & $100-200$ & $\%$ & 2 \\
\hline & & $200-300$ & $\%$ & 1 \\
\hline & & $>300$ & $\%$ & 0 \\
\hline
\end{tabular}

In addition, a variable concerning the use of organic methods of milk production named "organic" outlines the environmental impact of the production process, while the variable "typical races" highlights the presence of a strong link with tradition and the intention to valorize local inheritance. The whole set of abovementioned variables was used to compute the environmental index, based on the sum of the scores for the variables, and then normalized for analytical purposes (Index normalization: (Ii - Imin/Imax - Imin).

The social dimension of sustainability was estimated through the variables food experience, presence of restaurant, and social media. Food experience is described as the possibility to see the live experience of mozzarella making. Some urban cheese factories offer this opportunity to customers, with the specific aim of increasing their knowledge of traditional food production processes and, more importantly, as a chance for urban customers to get closer to rural culture and customs. This intention of involving customers in food-related activities is also represented by the variable presence of restaurant, which represents the possibility for customers to consume cheese-based dishes directly on site, thus emphasizing the freshness attribute of the food products sold. Finally, the variable social media relates to the use of social-media tools to promote the cheese factory activities and engage urban customers. Social media were selected amongst other different marketing strategies because of the inner nature of these innovative tools, able to enhance social involvement through interactivity. The above variables were used to compute the social index, based on the normalized sum of the scores for each variable. The economic dimension of sustainable mozzarella cheese production was evaluated by collecting data on market prices. The current value in Euro per kilo for each micro dairy 
was then compared with the average mozzarella price in Milan in the same period, gathered from official databases. Finally, the percentage difference between the two values (micro dairy vs. average mozzarella price) was used as a proxy of economic sustainability, since the affordability of urban food production has been considered the most relevant element to be evaluated. The economic index was then calculated by assigning a score ranging from 0 to 3 (Table 1), accounting for the price difference, which is subsequently normalized.

\subsection{Food Safety Analysis}

A sample of $2 \mathrm{~kg}$ of mozzarella cheese ( $125 \mathrm{~g}$ size) was collected from each urban dairy farmer. The purchase of samples was carried out the day before microbiological analysis, and all samples were kept at a temperature of $4{ }^{\circ} \mathrm{C}\left( \pm 2{ }^{\circ} \mathrm{C}\right)$ during transport and storage. The microbiological analyses focused on pathogenic microorganism markers (Listeria monocytogenes and Salmonella spp.). The detection of L. monocytogenes (analytical unit: $25 \mathrm{~g}$ ) was performed according to AFNOR BRD 07/4-09/98. Salmonella spp. detection (analytical unit: $25 \mathrm{~g}$ ) was carried out by using UNI EN ISO 6579: 2008. Moreover, hygienic markers were enumerated, specifically Escherichia coli, mesophilic aerobic bacteria, coagulase-positive staphylococci, and Bacillus cereus. In regard to Escherichia coli, Mesophilic aerobic bacteria and coagulase-positive staphylococci were enumerated by using $3 \mathrm{M}^{\mathrm{TM}}$ Petrifilm ${ }^{\mathrm{TM}}$ in accordance with the following methods: AFNOR 3M 01/08v06/01, AFNOR 3M 01/1-09/89 and AFNOR 3M 01/9-04/03, respectively, while Bacillus cereus parameter was enumerated according to UNI EN ISO 7932:2005.

The results obtained from the microbiological analyses were compared to the food safety standards developed by the Interdepartmental Research and Documentation Centre of Food Safety (Ce.I.R.S.A,) for the category "Pasteurized cheese or submitted to heat treatment at a higher temperature". The Ce.I.R.S.A guidelines (Table 2) provide, based on the level of contamination detected, four categories of microbiological quality (satisfactory, acceptable, unsatisfactory, and potentially damaging), each of which correspond to specific actions to be adopted according to the European Regulation CE 882/2004.

Table 2. Microbiological reference standards (https://www.ceirsa.org/) for the category pasteurized cheese or submitted to heat treatment at a higher temperature, submitted to microbiological investigation.

\begin{tabular}{cccc}
\hline Parameters & \multicolumn{2}{c}{ Ce.I.R.S.A Standard (CFU/g) } & Score \\
\hline Detection of Lysteria monocytogenes & Satisfactory & Absence in 25 g & 3 \\
& Potentially Damaging & Presence in 25 g & 0 \\
\hline Detection of Salmonella spp. & Satisfactory & Absence in 25 g & 3 \\
& Potentially Damaging & Presence in 25 g & 0 \\
\hline Enumeration of E. coli & Satisfactory & $<10^{2}$ & 3 \\
& Acceptable & $10^{2} \leq \mathrm{X}<10^{3}$ & 2 \\
& Unsatisfactory & $\geq 10^{3}$ & 1 \\
& Potentially Damaging & & 0 \\
\hline Enumeration of coagulase-positive staphylococci & Satisfactory & $<10$ & 3 \\
& Acceptable & $10 \leq \mathrm{X}<10^{2}$ & 2 \\
& Unsatisfactory & $\geq 102$ & 1 \\
& Potentially Damaging & & 0 \\
\hline Enumeration Bacillus cereus & Satisfactory & $<10^{2}$ & 3 \\
& Acceptable & $10^{2} \leq \mathrm{X}<10^{4}$ & 2 \\
& Unsatisfactory & $\geq 10^{4}$ & 1 \\
& Potentially Damaging & & 0 \\
\hline Enumeration Mesophilic aerobic bacteria & Satisfactory & $<10^{6}$ & 3 \\
& Acceptable & $10^{6} \leq \mathrm{X}<10^{7}$ & 2 \\
& Unsatisfactory & $\geq 10^{7}$ & 1 \\
\hline
\end{tabular}




\subsection{Volatile Compounds Profile}

The analyses of volatile compound (VOCs) were conducted by using the SPME coupled to GC/MS techniques according to previous research [31,32], quantitative analyses of selected VOCs were carried out by using the internal standard procedure and expressed as $\mathrm{ng}^{-\mathrm{g}^{-1}}$.

\subsection{Consumer Preference}

The consumer acceptability of urban mozzarella cheese was evaluated amongst a group of 60 Italian consumers selected on the basis of their regular consumption of mozzarella cheese, as well as their sex and age (32 females and 28 males between the ages of 20 and 60). During each sensory session, mozzarella cheese was cut into small cubes of equal thickness (about $30 \mathrm{~g}$ ) and served to the consumers at the same time. Two cubes per sample were presented to each consumer on white plastic plates, with pairs of cubes identified by 3-digit codes. Consumers were asked to evaluate the samples, assigning a numerical value between 1 (extremely dislike) and 9 (extremely like), based on overall acceptability and the acceptability of attributes that were selected as representative for the product: color, taste, and texture [33,34]. Furthermore, consumers expressed their intention to purchase each mozzarella cheese sample by a "yes" or "no" answer. About $50 \mathrm{~mL}$ of water and non-salted crackers were provided to the consumers between different tasting sessions. The six samples of mozzarella cheese were also compared with a sample of mozzarella cheese from industrial production amongst the most representative on the large retailer's reference market. The normalized version of the variable global preference was then used to estimate the consumer preference index, indicating the degree of consumer appreciation of the urban mozzarella samples. Statistical analyses of preference data were performed through one-way analysis of variance (ANOVA), with sensory parameters (preference and sensory descriptors) as effects. The significance of the effects was tested with F test, while means were compared with the Duncan test.

\section{Results and Discussion}

The following section summarizes the contents of the direct survey amongst the urban dairies in regard to process sustainability and the results of the analysis of the final product considering food safety and consumer preference.

\subsection{Environmental Sustainability}

One of the driving forces of the environmental sustainability of urban food production is the concept of a local food system, as demonstrated by several authors $[35,36]$.

Environmental sustainability must be evaluated within a short chain, and one of the main variables is the distance from the production site. From our results, four of five cases are in agreement with the abovementioned; in fact, Table 3 shows that, in micro dairies no. 1,2,3, and 4, the distance from the production site is really valorized.

Table 3. Environmental index and variables.

\begin{tabular}{ccccccc}
\hline No. & $\begin{array}{c}\text { Distance } \\
(\mathbf{k m})\end{array}$ & $\begin{array}{c}\text { Distance } \\
\text { (Coded) }\end{array}$ & $\begin{array}{c}\text { Raw } \\
\text { Material }\end{array}$ & Organic & $\begin{array}{c}\text { Typical } \\
\text { Races }\end{array}$ & $\begin{array}{c}\text { Environmental } \\
\text { Index }\end{array}$ \\
\hline 1 & 41 & 3 & 1 & 0 & 0 & 4 \\
2 & 30 & 3 & 1 & 0 & 0 & 4 \\
3 & 39 & 3 & 1 & 0 & 0 & 4 \\
4 & 54 & 2 & 1 & 0 & 0 & 3 \\
5 & 920 & 0 & 0 & 0 & 0 & 0 \\
\hline
\end{tabular}

Moreover, in one case, the micro dairy received milk from a distance much greater than 250 $\mathrm{km}$, thus generating high environmental impact in terms of greenhouse gas emissions due to the transportation phase, as highlighted by Coley et al. [37]. 
Moreover, with reference to the variable raw material, the survey revealed that, in one case, the on-site mozzarella production process starts from curd, instead of raw milk. Curd is an intermediate product of the mozzarella-making process, obtained by adding rennet to the milk to coagulate it. This means that the urban dairy is only in charge of the final steps of the process generally known as pasta filata, the operation of simultaneous stirring and heating of the curd, to obtain the typical mozzarella texture. In addition, all the dairies sampled present values equal to 0 for the organic variable, indicating that the milk used for production is never obtained through organic production methods.

This result is not particularly positive because, as stated by Grunert et al. [38], considerations about health and about the way the product is produced, for example, by organic production methods or with regard to animal welfare, characterize the quality perception of today's consumers.

Similarly, in all the cases, the typical races variable presents a null value, thus suggesting that the valorization of traditional animal races is not considered a strategic asset for dairy producers.

\subsection{Social Sustainability}

The social dimension of urban food production is considered particularly relevant, since it presents an opportunity to provide urban citizens not only with fresh and nutritious food, but also the chance to increase cultural knowledge and social cohesion.

Nevertheless, considering the variables selected to estimate the extent to which mozzarella urban production is socially sustainable, results are highly skewed (Table 4). More specifically, the social index has a value of zero if the micro dairy does not propose a food experience nor a restaurant and does not communicate with the public through social media. The absence of any forms of concrete engagement with the urban community could raise the need to reconsider the real purposes of urban food production and the call for a more structured food policy model able to valorize those activities that really take care of the social dimension of sustainability. As a matter of fact, the on-site visits at the micro dairies confirmed the fact that the type of information provided to customers in many cases appeared to be barely effective, i.e., small board with an indication of milk origin. Only in one case, urban food production was properly valorized and communicated with the proposal to take part in the cheese-making process and taste the fresh product, thanks to the presence of a restaurant.

Table 4. Social sustainability index and variables.

\begin{tabular}{ccccc}
\hline No. & Food Experience & Restaurant & Social Media & Social Index \\
\hline 1 & 1 & 0 & 1 & 2 \\
2 & 0 & 1 & 1 & 2 \\
3 & 0 & 0 & 0 & 0 \\
4 & 0 & 0 & 1 & 1 \\
5 & 1 & 1 & 0 & 2 \\
\hline
\end{tabular}

In regard to the social sustainability index, our results are not fully in line with those described by Canfora et al. [39]; the authors affirm that, in general, microenterprises have the promotion of biodiversity (i.e., products recognized as "local" by consumers) as their mission, and implementation of peri-urban agriculture produces positive effects on public goods, with overt environmental benefits. Moreover, Ilbery and Maye [40] found that the establishment of good personal relationships with customers is critically important, especially in buying specialty foods. The importance of relationships is also highlighted by Canavan et al. [41], according to whom a close relationship with producers and an understanding of the production context is important for consumers.

For all of these reasons, the results obtained make it clear that interaction/connection between local producers and consumers needs to be increased and strengthened in the micro dairies analyzed. 


\subsection{Economic Sustainability}

Although the economic dimension of sustainability was described by a single variable- the market price of mozzarella cheese produced in urban micro dairies-this variable could provide substantial insights on a further weakness of the existing urban food production.

Notably, Table 5 outlines that the market prices proposed by urban dairies are considerably greater than the average market value of the same product produced by the conventional food industry. Indeed, the average delta price is roughly $240 \%$ higher, with a maximum value of $387 \%$. Several factors related to the inner structure and management of industrial vs. small-scale production lead to consider a price premium for the latter product category, as obvious, in accordance with those reported by different authors [42,43].

Table 5. Economic index and variables.

\begin{tabular}{cccc}
\hline No. & Euro/kg & Ref. Price (Euro/kg) & $\Delta$ price $\%$ \\
\hline 1 & 12.8 & 4.1 & 212.20 \\
2 & 12.9 & 4.1 & 214.63 \\
3 & 20.0 & 4.1 & 387.80 \\
4 & 12.9 & 4.1 & 214.63 \\
5 & 11.9 & 4.1 & 190.24 \\
\hline
\end{tabular}

Nevertheless, on the one hand, the magnitude of the price difference appears to be in sharp contrast with a characteristic considered a milestone feature of urban food production, namely affordability and increased access to nutritious food. Although the enhancement of food safety is an issue in modern cities, data outline the risk that these innovative production systems could become part of the diet of high-income urban citizens only. However, on the other hand, studies [44-46] show that consumers like to buy local foods for a range of reasons, including environmental and health concerns, perception that local foods are high quality, the enjoyment of shopping at local outlets, and in order to support local farmers, economies, and communities.

\subsection{Food Safety}

The microbiological results are represented in Table 6 and show that Salmonella spp. and Listeria monocytogenes were absent in $25 \mathrm{~g}$ in all the samples in compliance to the EU Regulation No. 2073/2005.

Table 6. Food safety index based on Ce.I.R.S.A guidelines.

\begin{tabular}{|c|c|c|c|c|c|c|c|}
\hline No. & $\begin{array}{c}L . \\
\text { monocytogenes }\end{array}$ & $\begin{array}{l}\text { Salmonella } \\
\text { spp. }\end{array}$ & E. coli & $\begin{array}{c}\text { Coagulase }+ \\
\text { Staphylococci }\end{array}$ & B. cereus & $\begin{array}{c}\text { Mesophilic } \\
\text { Aerobic Bacteria }\end{array}$ & $\begin{array}{c}\text { Food Safety } \\
\text { Index }\end{array}$ \\
\hline 1 & 3 & 3 & 2 & 3 & 3 & 3 & 17 \\
\hline 2 & 3 & 3 & 3 & 3 & 3 & 3 & 18 \\
\hline 3 & 3 & 3 & 3 & 3 & 3 & 3 & 18 \\
\hline 4 & 3 & 3 & 3 & 3 & 3 & 3 & 18 \\
\hline 5 & 3 & 3 & 3 & 3 & 2 & 3 & 17 \\
\hline $\begin{array}{l}\text { Industrial } \\
\text { mozzarella }\end{array}$ & 3 & 3 & 3 & 3 & 3 & 3 & 18 \\
\hline
\end{tabular}

From this comparison, samples 3 and 4 appear satisfactory, with an optimal microbiological quality, while samples 1, 2, and 5 appear to be acceptable only for E. coli and Bacillus cereus parameters. Thus, results obtained highlighted, for some samples, the need for a more controlled food production chain, from raw materials to the final steps of the process, in accordance with Dias et al. [47]. 


\subsection{Consumer Preference}

Table 7 shows the output of the preference analysis amongst consumers. Results indicate that all the investigated parameters received mean values above five, except for sample no. 4 , which had lower values for several parameters. However, data related to purchase intention show great differences amongst products, with values ranging from $33.3 \%$ to $68.3 \%$. Even more interesting is the fact that the industrial product used as reference was, on average, the preferred one for all the descriptors, as well as for purchasing intention $(76 \%)$.

Table 7. Consumer acceptance.

\begin{tabular}{ccccccc}
\hline No. & Color & Taste & Texture & $\begin{array}{c}\text { Global } \\
\text { Preference }\end{array}$ & $\begin{array}{c}\text { \% Delta } \\
\text { Preference }\end{array}$ & $\begin{array}{c}\text { \% Purchase } \\
\text { Intention }\end{array}$ \\
\hline 1 & 6.9 & 5.9 & 5.8 & 5.8 & 12.1 & 61.6 \\
2 & 6.4 & 4.3 & 4.4 & 4.5 & 31.8 & 68.3 \\
3 & 7.2 & 6.3 & 6.4 & 5.2 & 21.2 & 33.3 \\
4 & 6.9 & 5.8 & 6.3 & 6 & 9.1 & 68.3 \\
5 & 6.1 & 4.9 & 5.6 & 5.2 & 21.2 & 46.6 \\
Industrial & 7.5 & 6.6 & 7 & 6.6 & 0 & 76.6 \\
Mozzarella & \multicolumn{7}{c}{ ***** Significance at $p<0.001}$.
\end{tabular}

It must also be taken into account that the industrial product is more controlled for each parameter, and the final product turns out to be more homogeneous from a sensorial point of view, when compared to an artisanal product, which is affected by the handcrafted processing of the operators.

\subsection{Determination of Volatile Compounds}

Table 8 details the volatile compounds detected that are responsible for a defect or off-flavor for milk and derived products such as cheeses, when abundant. Aldehydes, together with ketones, were the major secondary products of autoxidation of unsaturated fatty acids.

Table 8. Volatile compounds of milk responsible for its off-flavor.

\begin{tabular}{|c|c|c|c|c|c|}
\hline No. & $\begin{array}{l}\text { 2-Propanone } \\
\text { ng g }^{-1}\end{array}$ & $\begin{array}{c}\text { 3-Methyl- } \\
\text { 1-Butanol ng g }\end{array}$ & $\begin{array}{l}\text { Acetic Acid } \\
\text { ng. }^{-1}\end{array}$ & $\begin{array}{l}\text { Acetic Acid Methyl } \\
\text { Ester ng. } \mathbf{g}^{-1}\end{array}$ & $\begin{array}{c}\text { 3-Hidroxy- } \\
\text { 2-Butanone } \text { ng g }^{-1}\end{array}$ \\
\hline 1 & 51.35 & 1007.43 & 2073.83 & 4341.04 & 8814.15 \\
\hline 2 & 101.3 & 107 & 1754.46 & 111.18 & 610.19 \\
\hline 3 & 108.79 & 10.54 & 11.11 & 0 & 23.01 \\
\hline 4 & 85.04 & 854.83 & 0.65 & 2028.21 & 25.19 \\
\hline 5 & 19.9 & 180.62 & 0.85 & 51.73 & 132.52 \\
\hline $\begin{array}{l}\text { Industrial } \\
\text { mozzarella }\end{array}$ & 52.11 & 1.54 & 89.31 & 0 & 111.59 \\
\hline$f$ value & $17,197.571$ & 746.835 & 687.867 & 794.79 & 1120.923 \\
\hline
\end{tabular}

They are considered unstable and transitory compounds in cheese because these are reduced to alcohols or oxidized to corresponding acid. Moreover, alcohols as 3-methyl-1-butanol are associated with microbial fermentation phenomena. The sum of these volatile compounds could help to define the quality traits of cheese samples, especially if associated with microbiological and safety characteristics, as reported by Mauriello et al. [48].

\subsection{Summary of Results}

The normalization of all the indices provided the opportunity to simultaneously plot the results of the whole set of indices in a single map (Table 9). More specifically, for each dimension considered, 
the normalized index assumes the value of zero for the less sustainable case study, and the value of one for the most sustainable urban dairy.

Table 9. Index normalization values.

\begin{tabular}{cccccc}
\hline No. & $\begin{array}{c}\text { Economic } \\
\text { Index }\end{array}$ & $\begin{array}{c}\text { Environmental } \\
\text { Index }\end{array}$ & Social Index & $\begin{array}{c}\text { Food Safety } \\
\text { Index }\end{array}$ & $\begin{array}{c}\text { Consumer's } \\
\text { Preference }\end{array}$ \\
\hline 1 & 0.50 & 0.67 & 0.67 & 0.94 & 0.64 \\
2 & 0.50 & 0.67 & 0.67 & 1.00 & 0.50 \\
3 & 0.00 & 0.67 & 0.00 & 1.00 & 0.58 \\
4 & 0.50 & 0.50 & 0.33 & 1.00 & 0.67 \\
5 & 1.00 & 0.00 & 0.67 & 0.94 & 0.58 \\
\hline
\end{tabular}

Results indicate, as shown in Figure 1, that global sustainability is moderately low and unevenly distributed amongst the case studies considered. As for the food safety index, Figure 1 shows that it is the only indicator for which each case study assumes a value equal to or greater than 0.5 . This indicates that, besides the degree of sustainability of this specific urban food chain, a satisfactory level of food safety is always assured.

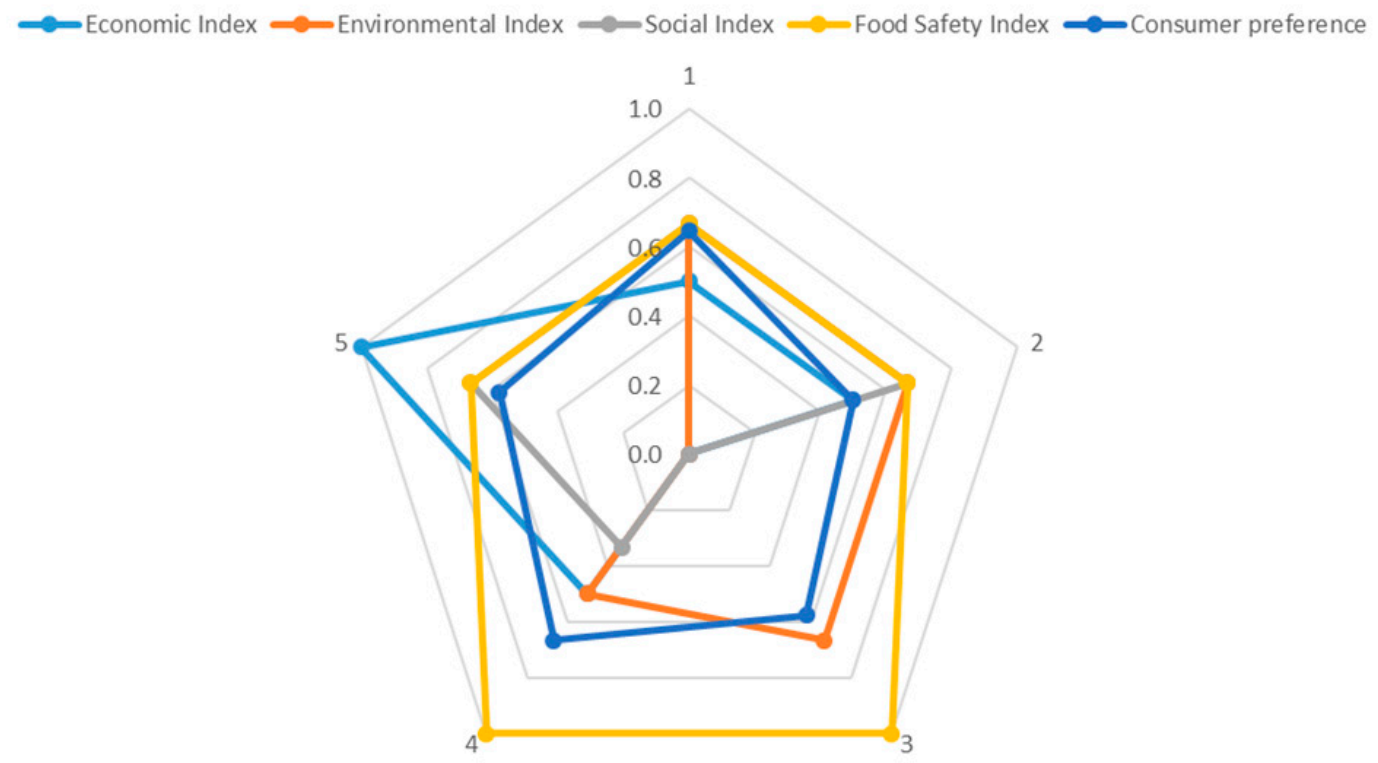

Figure 1. Food indices plot.

\section{Conclusions}

This research explored the components of urban food production by taking mozzarella cheese production in some micro dairies located in the Italian city of Milan as a case study. The aim was to propose a more global evaluation on the sustainability of this innovative phenomenon, considering a broader range of variables, including food safety and consumer preference.

The study showed that, although the drivers of urban food production have great potential, their concrete implementation presented many weaknesses and constraints. In detail, the study identified three main points, which deserve further attention. First, urban food production does not automatically mean that the food produced is environmentally sustainable. Secondly, the economic dimension of sustainability is hampered by the high market price of urban-produced mozzarella and consequently suggests that this type of production must be considered a niche product for high-income consumers, rather than a real option for the average urban citizen. The third aspect is the fact that, regarding sensory parameters and intention to purchase, consumers always preferred the industrial mozzarella cheese used as reference, from $190 \%$ to $387 \%$ less expensive than the urban-produced ones. 
Thus, it would appear that the reconnection between food producers and food consumers would not happen through the development of a specialty and niche market alone. Other aspects of the local food economy, notably the public procurement of local foods and cooperative/community food schemes, offer much greater potential for the development of food supply systems that are more economically, socially, and environmentally sustainable. In conclusion, this work suggests that the road to sustainable urban food systems needs to be implemented with appropriate actions of governance and food policies able to guide and support this transition, including educational measures and proper incentives for stakeholders.

Author Contributions: Conceptualization, M.C. and C.M.B.; methodology, M.C., V.V., S.P., and C.M.B.; formal analysis, M.C., V.V., G.F., D.T., S.P., and C.M.B.; resources, M.C., C.M.B., and S.P.; data curation, M.C., V.V., S.P., and C.M.B.; writing-original draft preparation, M.C., V.V., S.P., and C.M.B.; writing—review and editing, M.C., V.V., G.F., D.T., S.P., and C.M.B.; supervision, M.C. and C.M.B.; project administration, M.C., S.P., and C.M.B. All authors have read and agree to the published version of the manuscript.

Funding: This research received no external funding.

Conflicts of Interest: The authors declare no conflicts of interest.

\section{References}

1. Vieira, L.C.; Serrao-Neumann, S.; Howes, M.; Mackey, B. Unpacking components of sustainable and resilient urban food systems. J. Clean. Prod. 2018, 200, 318-330. [CrossRef]

2. Scharf, N.; Wachtel, T.; Reddy, S.E.; Säumel, I. Urban Commons for the Edible City—First Insights for Future Sustainable Urban Food Systems from Berlin, Germany. Sustainability 2019, 114, 966. [CrossRef]

3. United Nations. The 2018 Revision of World Urbanization Prospects 2018. Available online: https://www.un. org/development/desa/publications/2018-revision-of-world-urbanization-prospects.html (accessed on 16 January 2020).

4. Battersby, J.; Haysom, G. Linking urban food security, urban food systems, poverty and urbanisation. In Urban Food Systems Governance and Poverty in African Cities; Routledge: London, UK, 2018; pp. 56-67.

5. Badami, M.G.; Ramankutty, N. Urban agriculture and food security: A critique based on an assessment of urban land constraints. Glob. Food Secur. 2015, 4, 8-15. [CrossRef]

6. De Cunto, A.; Tegoni, C.; Sonnino, R.; Michel, C.; Lajili-Djalaï, F. Food in Cities: Study on Innovation for a Sustainable and Healthy Production, Delivery, and Consumption of Food in Cities. 2017. Available online: https://ec.europa.eu/research/openvision/pdf/rise/food_in_cities.pdf (accessed on 16 January 2020).

7. Pothukuchi, K.; Kaufman, J.L. Placing the food system on the urban agenda: The role of municipal institutions in food systems planning. Agric. Hum. Values 1999, 162, 213-224. [CrossRef]

8. Feenstra, G. Creating space for sustainable food systems: Lessons from the field. Agric. Hum. Values 2002, 192, 99-106. [CrossRef]

9. Cicatiello, C.; Pancino, B.; Franco, S. Un modello per la Valutazione Della Sostenibilità Territoriale Delle Filiere Agroalimentari: Struttura e Applicazione Alla Sfera Ambientale. 2012. Available online: https: //ageconsearch.umn.edu/record/124383 (accessed on 16 January 2020).

10. Blay-Palmer, A.; Santini, G.; Dubbeling, M.; Renting, H.; Taguchi, M.; Giordano, T. Validating the city region food system approach: Enacting inclusive, transformational city region food systems. Sustainability 2018, 105, 1680. [CrossRef]

11. Charatsari, C.; Kitsios, F.; Stafyla, A.; Aidonis, D.; Lioutas, E. Antecedents of farmers' willingness to participate in short food supply chains. Br. Food J. 2018, 12010, 2317-2333. [CrossRef]

12. Kneafsey, M.; Venn, L.; Schmutz, U.; Balázs, B.; Trenchard, L.; Eyden-Wood, T.; Blackett, M. Short food supply chains and local food systems in the EU. A state of play of their socio-economic characteristics. JRC Sci. Policy Rep. 2013, 25911, 1-128.

13. Todorovic, V.; Maslaric, M.; Bojic, S.; Jokic, M.; Mircetic, D.; Nikolicic, S. Solutions for More Sustainable Distribution in the Short Food Supply Chains. Sustainability 2018, 1010, 3481. [CrossRef]

14. Brown, E.; Dury, S.; Holdsworth, M. Motivations of consumers that use local, organic fruit and vegetable box schemes in Central England and Southern France. Appetite 2009, 532, 183-188. [CrossRef] 
15. Renting, H.; Marsden, T.K.; Banks, J. Understanding alternative food networks: Exploring the role of short food supply chains in rural development. Environ. Plan. A 2003, 353, 393-411. [CrossRef]

16. European Commission. Regulation EU No 1305/2013 of the European Parliament and of the Council. Support for rural development by the European Agricultural Fund for Rural Development EAFRD and repealing Council Regulation EC No 1698/2005. OJL 2013, 347, 487-548.

17. Abel, J.; Thomson, J.; Maretzki, A. Extension's role with farmers' markets: Working with farmers, consumers, and communities. J. Ext. 1999, 375, 150-165.

18. Hilchey, T.L.; Gillespie, G.W. Farmers' Markets and Rural Economic Development, Community Agriculture Development Series; Cornell University, Farming Alternatives Program, Department of Rural Sociology: Ithaca, NY, USA, 1995.

19. Landry, C. The Creative City: A Toolkit for Urban Innovators; Routledge: London, UK, 2012; ISBN 978-1844075980.

20. Bianchini, M.; Maffei, S. Microproduction Everywhere: Defining the Boundaries of the Emerging New Distributed Microproduction Socio-Technical Paradigm; Bloomsbury: London, UK, 2016; ISBN 9780857855534.

21. Van Veenhuizen, R.; Danso, G. Profitability and Sustainability of Urban and Periurban Agriculture; Food Agriculture Organization (FAO): Rome, Italy, 2007; Volume 19, ISBN 978-92-5-105881-7.

22. Specht, K.; Siebert, R.; Hartmann, I.; Freisinger, U.B.; Sawicka, M.; Werner, A.; Dierich, A. Urban agriculture of the future: An overview of sustainability aspects of food production in and on buildings. Agric. Hum. Values 2014, 311, 33-51. [CrossRef]

23. Horst, M.; McClintock, N.; Hoey, L. The intersection of planning, urban agriculture, and food justice: A review of the literature. J. Am. Plan. Assoc. 2017, 833, 277-295. [CrossRef]

24. Mok, H.F.; Williamson, V.G.; Grove, J.R.; Burry, K.; Barker, S.F.; Hamilton, A.J. Strawberry fields forever? Urban agriculture in developed countries: A review. Agron. Sustain. Dev. 2014, 341, 21-43. [CrossRef]

25. James, S. Jennifer Cockrall-King: Food and the city: Urban agriculture and the new food revolution. Agric. Human Values 2016, 331, 227-228. [CrossRef]

26. Ilbery, B.; Maye, D. Food supply chains and sustainability: Evidence from specialist food producers in the Scottish/English borders. Land Use Policy 2005, 224, 331-344. [CrossRef]

27. Aubry, C.; Kebir, L. Shortening food supply chains: A means for maintaining agriculture close to urban areas? The case of the French metropolitan area of Paris. Food Policy 2013, 41, 85-93. [CrossRef]

28. Jablonski, B.B.; Carolan, M.; Hale, J.; Thilmany McFadden, D.; Love, E.; Christensen, L.; Jablonski, K.E. Connecting Urban Food Plans to the Countryside: Leveraging Denver's Food Vision to Explore Meaningful Rural-Urban Linkages. Sustainability 2019, 117, 2022. [CrossRef]

29. Assolatte. Italian Mozzarella Market 2015. Available online: https://know.cerved.com/it/studi-e-analisi (accessed on 16 January 2020).

30. Bampidis, P.H.; Robinson, P.H. Citrus by-products as ruminant feeds: A review. Anim. Feed Sci. Technol. 2006, 128, 175-217. [CrossRef]

31. Valnegri, L.; Panseri, S.; Franzoni, M.; Antoniazzi, V.; Soncin, S.; Soncini, G.; Chiesa, L.M. Chemical composition, fatty acid profile and food safety criteria to characterise an artisanal Italian mountain cheese from goats grazin on pastures. Milchwissenschaft 2011, 66, 286-289.

32. Panseri, S.; Soncin, S.; Chiesa, L.M.; Biondi, P.A. A headspace solid-phase microextraction gas-chromatographic mass-spectrometric method HS-SPME-GC/MS to quantify hexanal in butter during storage as marker of lipid oxidation. Food Chem. 2011, 1272, 886-889. [CrossRef]

33. Munoz, A.M.; King, S.C. International Consumer Products Testing Across Cultures and Countries; ASTM International: West Conshohocken, PA, USA, 2007; Available online: https://www.astm.org/DIGITAL_ LIBRARY/MNL/PAGES/MNL11101M.htm (accessed on 16 January 2020).

34. MacFie, H.J.; Bratchell, N.; Greenhoff, K.; Vallis, L.V. Designs to balance the effect of order of presentation and first-order carry-over effects in hall tests. J. Sens. Stud. 1989, 42, 129-148. [CrossRef]

35. Kizos, T.; Vakoufaris, H. Valorisation of a local asset: The case of olive oil on Lesvos Island, Greece. Food Policy 2011, 36, 705-714. [CrossRef]

36. Aguiar, L.D.C.; Del Grossi, M.E.; Thomé, K.M. Short food supply chain: Características na agricultura familiar. Ciência Rural 2018, 48, e20170775. [CrossRef]

37. Coley, D.; Howard, M.; Winter, M. Local food, food miles and carbon emissions: A comparison of farm shop and mass distribution approaches. Food Policy 2009, 34, 150-155. [CrossRef] 
38. Grunert, K.G.; Bech-Larsen, T.; Bredahl, L. Three issues in consumer quality perception and acceptance of dairy products. Int. Dairy J. 2000, 10, 575-584. [CrossRef]

39. Canfora, I. Is the short food supply chain an efficient solution for sustainability in food market? Agric. Agric. Sci. Procedia 2016, 8, 402-407. [CrossRef]

40. Ilbery, B.; Maye, D. Alternative (shorter) food supply chains and specialist livestock products in the Scottish and English border. Environ. Plan. A 2005, 37, 823-844. [CrossRef]

41. Canavan, O.; Henchion, M.; O'Reilly, S. The use of the Internet as a Marketing Channel for Irish Speciality Food. Int. J. Retail Distrib. Manag. 2007, 35, 178-195. [CrossRef]

42. Lencucha, J.; Williams, M.; Capjack, L.; Gross, V.M. Farmers Markets in Alberta: A Direct Channel of Distribution; Food and Rural Development: Alberta, AB, Canada, 1998.

43. Henneberry, S.R.; Whitacre, B.; Agustini, H.N. An Evaluation of the Economic Impacts of Oklahoma Farmers Markets. J. Food Distrib. Res. 2009, 40, 64-78.

44. Kirwan, J. Alternative Strategies in the UK Agro-Food System: Interrogating the Alterity of Farmers' Markets. Sociol. Rural. 2004, 44, 396-415. [CrossRef]

45. Seyfang, G. Avoiding Asda? Exploring Consumer Motivations in Local Organic Food Networks. Local Environ. 2008, 13, 187-201. [CrossRef]

46. Holloway, L.; Cox, R.; Dowler, E.; Kneafsey, M.; Tuomainen, H.; Venn, L. Reconnecting Consumers, Producers and Food: Exploring Alternatives; Cultures of Consumption: London, UK, 2019.

47. Dias, M.A.C.; Sant'Ana, A.S.; Cruz, A.G.; José de Assis, F.F.; de Oliveira, C.A.F.; Bona, E. On the implementation of good manufacturing practices in a small processing unity of mozzarella cheese in Brazil. Food Control 2012, 24, 199-205. [CrossRef]

48. Mauriello, G.; Moio, L.; Genovese, A.; Ercolini, D. Relationships between flavoring capabilities, bacterial composition, and geographical origin of natural whey cultures used for traditional water-buffalo mozzarella cheese manufacture. J. Dairy Sci. 2003, 86, 486-497. [CrossRef]

(C) 2020 by the authors. Licensee MDPI, Basel, Switzerland. This article is an open access article distributed under the terms and conditions of the Creative Commons Attribution (CC BY) license (http://creativecommons.org/licenses/by/4.0/). 